\title{
Performance of baited traps for integrated management of Hypothenemus hampei Ferrari (Coleoptera: Scolytinae) in a conilon coffee crop in Rondônia State, Brazil
}

\author{
Moisés Santos De Souza ${ }^{1 \varpi}$, José Nilton Medeiros Costa ${ }^{2}$, Marcelo Curitiba Espindula ${ }^{2}$ \& \\ Alexandre de Almeida e Silva ${ }^{3}$
}

1. Universidade Federal do Amazonas, Laboratório de Fitossanidade do IEAA/UFAM, Brazil. 2. Embrapa Rondônia, Centro de Pesquisa Agroflorestal de Rondônia, Brazil. 3. Universidade Federal de Rondônia, Laboratório de Bioecologia de Insetos, Brazil.

\section{EntomoBrasilis 13: e913 (2020)}

\author{
Edited by: \\ William Costa Rodrigues \\ Article History: \\ Received: 25.vi.2020 \\ Accepted: 04.x.2020 \\ Published: $26 . x .2020$ \\ Corresponding author: \\ Moisés Santos De Souza \\ 乃 moisesantos@ufam.edu.br \\ Funding agencies: \\ \& CAPES - Coordenação de \\ Aperfeiçoamento de Pessoal de Nível \\ Superior
}

\begin{abstract}
Hypothenemus hampei (Ferrari) is an important pest worldwide. Methods of monitoring and control using baited traps are not yet established in coffee plantations in the Brazilian Amazon. The objective of this work was to record, for the first time, results of the use of baited traps in coffee plantation located in Rondônia, in favor of the control and pest monitoring. Two areas were delineated: i) with use of the traps baited with ethanol/methanol (1:1), treatment; ii) without use of traps (control). For comparison of results, two factors were considered: damaged fruits (damage by $H$. hampei) and infested ( $H$. hampei inside of fruits). It was observed higher levels of damaged fruits per plants in the control area compared to the area where traps were used. The density of the pest population per plants found on infested fruits was also higher in the control area compared to the trapping area. These results suggest that traps baited with ethanol/methanol (1:1) are an effective alternative for population control of pest also in the coffee plantations in Rondônia, where there is no such management with this tool. Use of the baited traps to monitor the insect accurately revealed that the flight stimulus of the colonizing females is influenced by values of the environmental variables. According to the results, colonizing females are more active in the afternoon. Therefore, in order to achieve more efficient control of $\mathrm{H}$. hampei, the best time to apply control agents is between 2:00 pm and 6:00 pm.
\end{abstract}

Keywords: Coffea canephora; Coffe berry borer; Population control; Monitoring.
$\Pi$ n n Brazil, the world's largest coffee producer, the first seedlings of Coffea sp. (Gentianales: Rubiaceae) were $\square$ planted in the Amazon region (SCALON et al. 2011; MARCOLAN \& Espíndula 2015). However, in this part of the world, particularly in Rondônia, environmental conditions with a high potential for susceptibility to pests commonly found in coffee plantations prevail. Thus, the coffee berry borer, Hypothenemus hampei Ferrari (Coleoptera: Curculionidae: Scolytinae) is one of the main pests that compromises the production of coffee plantations in the Brazilian Amazon (DE SouzA et al. 2014, 2018).

Alcohol traps have been used to mass control and monitor of $H$. hampei (ARISTIZÁBAL et al. 2015; LARSON 2016). Although the reports indicate the effectiveness of the baited traps for population control and monitoring of $H$. hampei (Dufour \& FrÉROT 2008; ArISTIZÁBAL et al. 2016), this tool is not yet used for this purpose in coffee plantations in the Brazilian Amazon, in favor of the control and monitoring of this pest, being the technological level very low in most of the plantations in this part of the world. On the continuous use of the traps for the mass control of $H$. hampei, it is reported that its use, is intended to decrease the population of colonizing females that survive on dried fruits left in the field, this includes during the off-season period (VEGA et al. 2009; Fernandes et al. 2014).

Climatic data is relevant to agricultural systems, since it is indispensable information for pest management in these environments (MorRIs et al. 2015). Therefore, in integrated pest management (IPM) programs of $\mathrm{H}$. hampei, considering the climatic conditions of the environment in order to understand its bioecological and behavioral aspects, according to the peculiarities of the place where the coffee crop is inserted, is extremely important (ReBAUDo \& DANGLES 2015). There is still no such information on coffee plantations in the Amazon region that would provide indications of more appropriate management of this pest considering these factors in this region.

Therefore, the objective of this study was to investigate the effect of the use of baited traps during off-season on the population of $\mathrm{H}$. hampei and its behavior according to the study site's environmental variables, in order to encourage and establish effective and sustainable strategies to control this important pest in coffee plantations of the Brazilian Amazon.

\section{MATERIAL AND METHODS}

\section{Experimental site and traps}

Area of study and traps. The evaluation of the baited traps was conducted in the Experimental Field of the Brazilian Agricultural Research Company (Embrapa Rondônia) located in the municipality of Porto Velho, Brazil $\left(8^{\circ} 48^{\prime} 01.47^{\prime \prime} \mathrm{S}\right.$, 
$63^{\circ} 51^{\prime} 03.61^{\prime \prime}$ W). A area of Coffea canephora, Pierre (Conilon) - BRS Ouro Preto variety was used in full production. The tillage was planted on December 20, 2008. The plants were distributed in the area in single rows, spacing $2.0 \mathrm{~m}$ (between plants) by $3.0 \mathrm{~m}$ between rows, equivalent to 1,666 plants per hectare. The plants were pruned for production in July 2013 , and from the emergence of new shoots, five (5) stems were maintained per plant. The coffee trees were conducted in dry conditions, without irrigation, and the fertilizations were carried out following the technical recommendations for the culture, in the region (MARCOLAN et al. 2009). The area of the evaluation of the traps and the control area were delimited distant 80 meters from one another, within the bounds of 1 ha. For each valuation area, 16 rows planted including approximately 500 plants.

The climate of the region, by classification of Köppen Am (rainy tropical) with rainy summer (October to May) and dry winter (June to September). According to the weather conditions, average monthly temperatures range from $30^{\circ} \mathrm{C}$ in summer to $17^{\circ} \mathrm{C}$ in winter. The average annual precipitation is 2,200 $\mathrm{mm}$, with rainy season from October to May and the dry season from June to September (Alvares et al. 2013).

Impact traps made with two-liter polyethylene (PET) bottles with a $12 \times 9 \mathrm{~cm}$ rectangular side opening were used. The traps were painted red on the inside and outside. Glass vials $(10 \mathrm{~mL})$ with rubber caps were used as attractant diffusers. In each of these diffusers, $7 \mathrm{~mL}$ of the attractants (99.8\%) ethanol:methanol (1:1) (Química Moderna ${ }^{\circledR}$ ) was placed. The rubber caps were drilled in order to insert metal straws (1 straw in each glass vials) with $3.8 \mathrm{~mm}$ diameter openings for the volatiles to exit the vials.

In each area surveyed, four traps were installed by blocks separated by the two plant row, alternately. This way, a total of $24(6 \times 4)$ equidistant traps were distributed throughout the six blocks. The methodological design of traps installed between the plants was adopted at a height of $1.2 \mathrm{~m}$ with a distance of approximately 15 meters each other (Dufour \& FRÉROT 2008).

After impact on the trap wall, the insects fell into the collection recipient which was filled with water mixed with $10 \%$ ethylene glycol (J.T.Baker ${ }^{\circledR}$ ) and $1 \%$ neutral detergent, where they died by drowning. The attractive were replaced every week. Samples were collected using filter paper. After each collection, the insects were properly, packaged and taken to the Laboratory of Entomology (Embrapa Rondônia) for sorting and counting.

Evaluation of the baited traps as a tool to control the population of $\boldsymbol{H}$. hampei. For comparison purposes, damaged and infested fruits (presence of eggs, larvae, pupae or adults) were considered in coffee fruits in the two areas investigated. Samples of fruits in the harvest month (May/2016) were collected in the following areas: i) where the traps were used during the off-season and ii) the control area where there were no traps. The purpose of this methodology was to evaluate the effect of the use of traps during the flowering and graining stage (25 weeks, October/2015 to March/2016), considered as an off-season, on the level of infestation in mature fruits at the peak of the next harvest (May/2016).

The sampling method for evaluation of the damaged and infested fruits was based on the visual observation on the four sides of the plant of ten (10) fruits of each third of the crown of the plant, through simple random sampling: lower, medium and higher, resulting in thirty (30) fruits in each side of the plant observed, totaling the observation of one hundred and twenty (120) fruits per plant $(4 \times 30)$. In both areas of the experiment, nine (9) blocks, separated by the two plant row alternately, were evaluated and in each one, twenty four (24, randomly selected) plants were observed, totaling the observation of two hundred and sixteen (216) plants. The damaged fruits were collected and duly identified, conditioned and transported to the Entomology Laboratory of Embrapa Rondônia to observe the occurrence or not of infestation.

In order to evaluate the population dynamic of $H$. hampei in the off-season, the population of the pest trapped in the traps was counted weekly (21 weeks, November/2015 to March/2016). Also, only in the area with the use of baited traps, the impact of the remaining fruits was evaluated in the reproductive maintenance of the insect before harvest. For this, a plant was previously selected in each block of the area, 05 (five) fruits of the plant and 05 (five) fallen on the soil were collected weekly. The collected fruits were packed in paper bags, duly labeled, and sent to Embrapa Rondônia Entomology Laboratory. This occurred in the months of October/2015 to March/2016.

In the laboratory, the fruits were dissected and evaluated for observation of the broached and infested fruits. Damaged fruits were those that were only with the absence of $H$. hampei, fruits with the presence of $H$. hampei at any stage of their life cycle (egg, larva, pupa, adult), were considered infested. The percentage corresponded to the proportion of damaged fruits with the total number of fruits collected and analyzed.

\section{Hypothemenus hampei abundance and climatic} parameters during the daytime period. Since this pest has a behavior to stay inside the fruits, the longest lifetime, this study demonstrates, how the different climatic factors affect of the flight activity of the insect. This allows to know the best time to apply their control agents, in order to maximize the chance of direct contact of the insect with the product (chemical or biological). In this experimental phase, $H$. hampei abundance was related to environmental variables during the day, in the area where the traps were used during the off-season. Six different time points were observed between 6:00 am and 6:00 pm (12 hours of observation) during a period when the fruits were ripe, at the peak of the harvest in May/2016. Observations occurred at two-hour intervals, using traps baited with ethanol-methanol (1:1). At each observation time, the following abiotic factors were considered: temperature $\left(\mathrm{T}^{\circ} \mathrm{C}\right)$, relative air humidity, wind gusts $(\mathrm{m} / \mathrm{s})$ and solar radiation $\left(\mathrm{Kj} / \mathrm{m}^{2}\right)$. These data were collected from the meteorological station in the Embrapa Rondônia experimental field, 500 meters of the area of study. The observations occurred over five consecutive days (totaling 60 hours of observation) in the last week of the coffee harvest, when the pest was in its full reproductive cycle due to the optimal condition of the ripe fruits for their reproduction. For every hour of observation, there were 24 replicates. Since the collections were performed every two hours, for practicality and agility, transparent plastic tubes with approximately $30 \mathrm{~mL}$ of water with detergent were attached to the bottleneck of the traps to capture and count the insects "in loco" (Figure 1).

Statistical Analyses. For the analysis of the effect of the use of traps for the mass control of $\mathrm{H}$. hampei, we compared the number of damaged and infested fruits of the two areas investigated. For this, the non-parametric Wilcoxon and Median tests were applied at the $5 \%$ level of significance $(p<$ 0.05) by software R CORE TEAM (2017). The normality of the data was tested by the Shapiro-Wilk test. The count of $\mathrm{H}$. hampei collected in the traps at each time along each environmental variable was adopted to indicate the abundance of the insect 


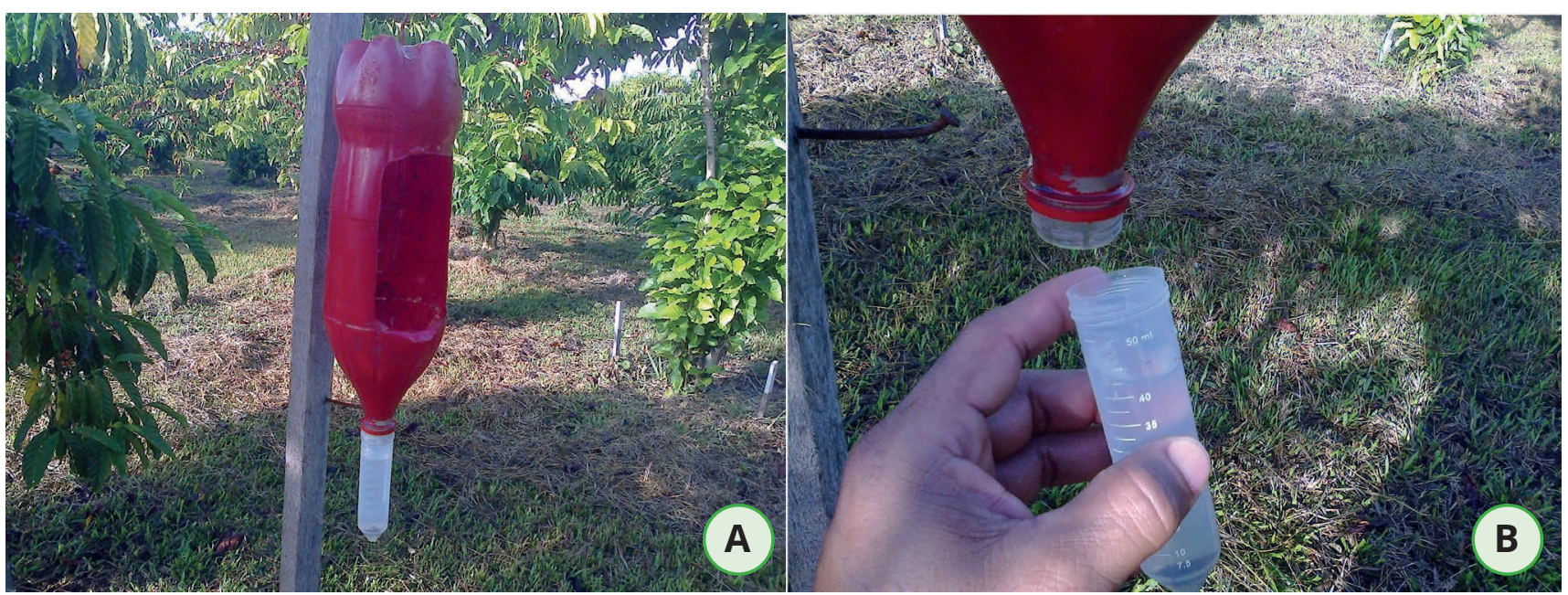

Figure 1. Plastic tubes in coffee monoculture (C. canephora) from Embrapa Rondônia Experimental Station, in the municipality of Porto Velho, Rondônia, used in the traps for collecting (A) and counting (B) "in locu" of H. hampei at each collection time. (Photo: MS De Souza)

according to the values of light, wind, temperature and relative humidity. The meteorological data were submitted to an analysis of variance (ANOVA) followed by the Tukey test $(p<0.05)$. The abundance of $H$. hampei was compared with the climatic variables according to the collection schedules and verified from Pearson's correlation analysis at the 1\% probability level $(p<0.01)$, using the statistical package SISVAR (2016).

\section{RESULTS AND DISCUSSION}

Evaluation of traps as a control tool. The catches that occurred of $\mathrm{H}$. hampei during the off-season resulted in the reduction of infested fruits and consequently damaged fruits. The use of the traps during the off-season demonstrated that this tool has a negative impact on the population of $H$. hampei and consequently on the damages caused in the fruits for the next maturation and harvest period. There was a difference in the level of damaged fruits $(p<0.04)$ between the two studied areas (Figure 2). In addition, a higher proportion of fruits infested in the control area was observed. The median was higher $(p<0.04)$, five times more in relation to the area where the baited traps were used (Figure 2).

As observed in this study, the population of colonizing females during the off-season period declined sharply from October to the months before harvest, with the pest population relatively low at the end of the off-season (Figure 3). The data of this study suggest that the population of $H$. hampei that survives in the remaining fruits finishes the diapause around the month of February, where the first immature forms of the insect appear in the remaining fruits
(Figure 4). Therefore, these fruits, mainly of the soil (Figure 4), determine the levels of infestations in the next harvest. Therefore, the mass control of $H$. hampei with traps baited during the off-season has been shown to be promising in the control of this pest, including as demonstrated by this study, in coffee plantations in the Amazon region, where there is absence of control method and monitoring with this tool.

The effectiveness of the $H$. hampei catch in the offseason period characterizes a strategic part of integrated management, although the results appear in a variable way in the other producing coffee regions in the world (BARRERA et al. 2006). In this study, it was observed that the first fruits infested during the off-season, occur in the remaining fruits fallen in the soil, in the months of February and March (Figure 4). Since in this period there are no suitable fruits in the plants for the colonizing females of $\mathrm{H}$. hampei, this suggests that the dry fruits remaining in the soil are incipient determinants for the reproductive cycle of the next generations of the pest. It is mentioned that the fruits remaining in the plants and in the post-harvest soil, is determinant in the initial size of the population in the multiplication phase, and consequently in the infestation intensities (MATHIEU et al. 1999).

In this context, there are records that the effectiveness of the traps can reduce the percentage of damaged fruits by 57\% (FERNANDEs et al. 2014). Other results also corroborate this information and show that the damage caused by $H$. hampei can still be reduced to between $12 \%$ and $80 \%$ relation to the adjacent areas without traps, and the traps are recommended to control this pest (MATHIEU et al. 1999; Villacorta-Mosqueira et al. 2001). Therefore, baited traps are

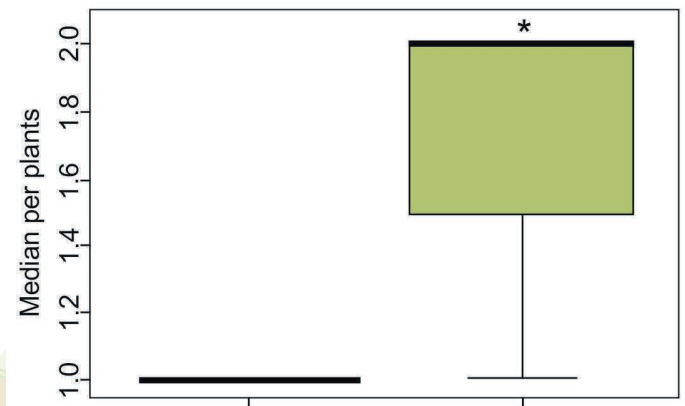

Fruits damaged

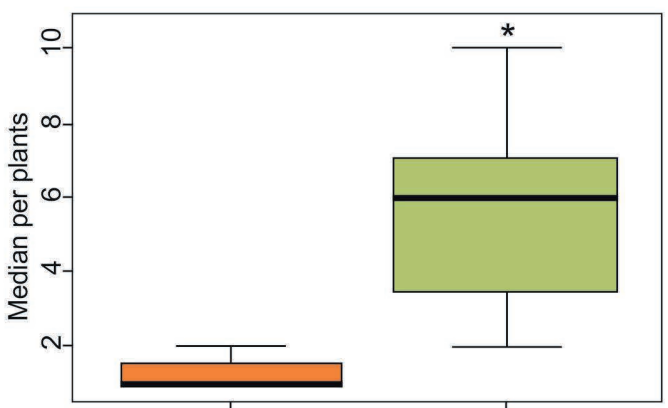

Infested fruits

Area with traps $\quad$ Area control (without traps)

Figure 2. Comparison of the median per plants of damaged fruits, infested fruits observed at harvest time (May/2016) in the area where there was use of baited traps and in the area without use of traps (control). The data come from observations of 216 plants (120 fruits per plant) in coffee monoculture (C. canephora) from Embrapa Rondônia Experimental Station, in the municipality of Porto Velho, Rondônia. The median in columns with asterisks are significantly different (Wilcoxon Test, $p>0.05$ ). 


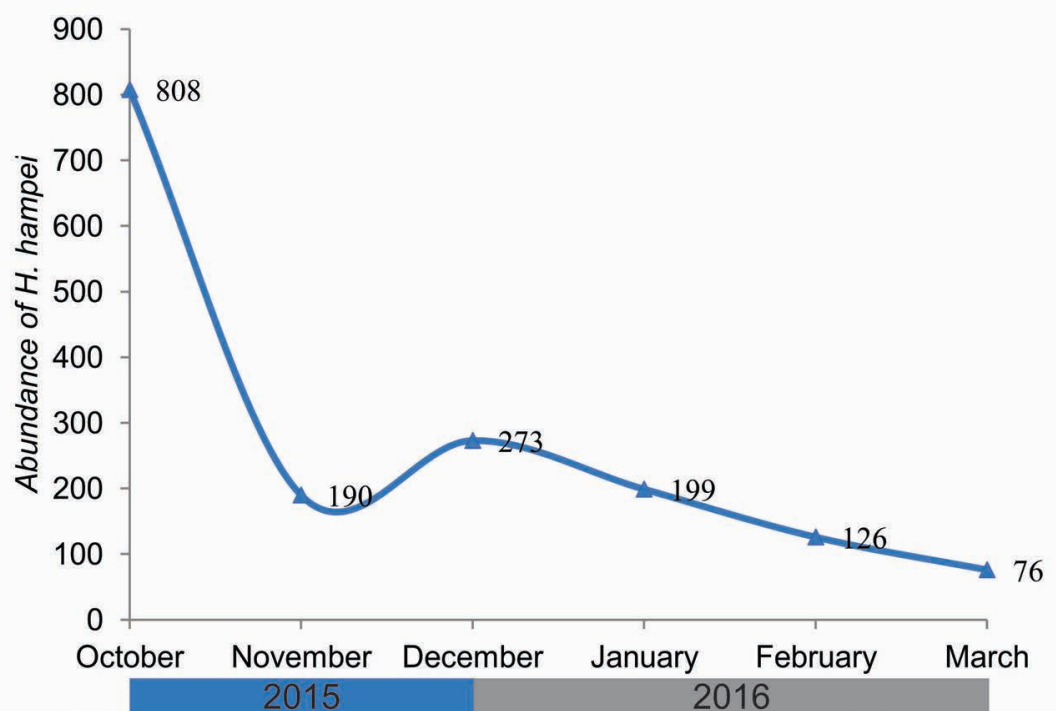

Figure 3. Population dynamics of $H$. hampei during the off-season in coffee monoculture (C. canephora) from Embrapa Rondônia Experimental Station, in the municipality of Porto Velho, Rondônia. The data come from the capture of insects between the months of October/2015 to March/2016.

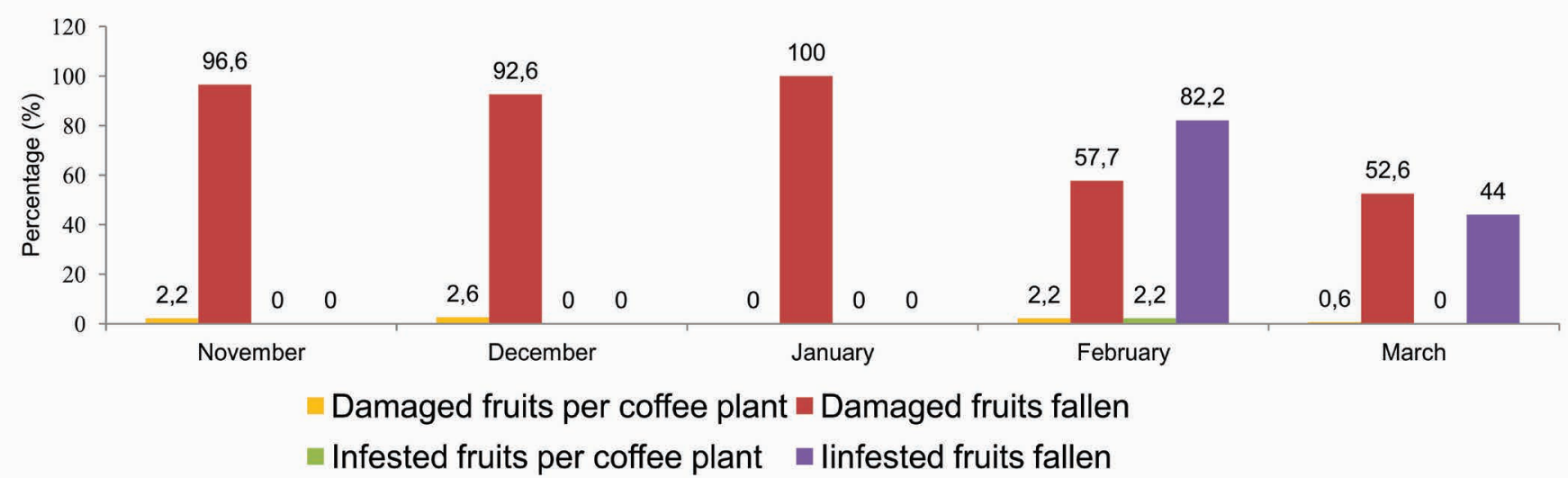

Figure 4. Percentage of damaged fruits and infested fruits (presence of eggs, larvae, pupae or adults) in the off-season (November/2015 to March/2016) of fruits collected in plants and soil (fallen fruits) in the area with the use of baited traps in coffee monoculture (C. canephora) from Embrapa Rondônia Experimental Station, in the municipality of Porto Velho, Rondônia.

interesting for the massive control of colonizing or postdiapause $H$. hampei females during off-season. This efficacy is demonstrated in other studies with traps also during the off-season (Dufour 2002). Moreover, this is relevant for coffee plantations in the Western Amazon because there is usually no technical harvesting procedure in these plantations, resulting in the presence of many remaining fruits in the field, mainly in the soil.

As a general result of this study, we highlight the reduction of up to five times the median of the pest per plant in the tillage through the use of the traps in the off-season (Figure 2). Thus, the capture of the pest during intensive and repetitive harvesting with the baited traps can generate satisfactory results, reducing the damage caused to the fruits during the harvest period, as explicit in this study. In this context, it was observed after three years of massive catches in experimental fields in Mexico, significant reductions of fruit infested by H. hampei (BARRera et al. 2006). Thus, this method can be implemented in coffee plantations located in Rondônia, which still needs more appropriate and sustainable procedures for the management and control of this pest.

Relationship between environmental variables and daytime abundance of $\boldsymbol{H}$. hampei. The abundance of females in flight activity in search of new fruits to colonize was observed to be dependent on certain evaluated environmental variables. Abundance correlated negatively with $\mathrm{RH}$ (Pearson = -0.89), and positively with temperature $($ Pearson $=0.88)$, sunlight $($ Pearson $=0.93)$ and wind gusts
$($ Pearson $=0.93)($ Table 1$)$.

Higher abundance of insects in flight activities are found from 2:00 p.m., when there is a marked increase in light, wind and temperature, with the exception of the $\mathrm{RH}$ that decreases at the same time, in contrast to the other variables. For all these environmental variables, there is a difference $(p>0.05)$ from 2:00 p.m. in relation to the morning hours (Table 2 ).

When light reaches its value between 2013.6 and $2135.6 \mathrm{kj} /$ $\mathrm{m} 2$, it is observed the greatest flight activity of $\mathrm{H}$. hampei (Figure $5 \mathrm{a}$ ). In relation to wind, the abundance is crescent from the time when the velocity reaches the value $3.7 \mathrm{~m} / \mathrm{s}$ (Figure 5b). Regarding temperature, maximum abundance was observed between 29.5 and $31.5{ }^{\circ} \mathrm{C}$ (Figure 5c). This is corroborated by other studies; for example, low $\mathrm{H}$. hampei flight activity is attributed to the milder temperatures in coffee plantations intercropped with bananas (ARISTIZÁBAL et al. 2015), thus demonstrating that the abundance of this insect can be conditioned by relatively higher temperatures in the environment. In relation to the $\mathrm{RH}$ variable, the flight activity of $H$. hampei is related to the decrease, observing the activation of the insect also from 2:00 pm when it reaches $71.4 \%$, reaching greater flight activity in the values between 70 and $62 \% \mathrm{RH}$ (Figure $5 \mathrm{~d}$ ). These results indicate that the flight activity of $H$. hampei occurs mainly in the afternoon, since the optimal values for the insect flight stimulus occur from 2:00 pm. Although in this sample period there is a relative low population density (Figures $5 \mathrm{a}$-d), it was found that the few insects were active only in the afternoon, with 
Table 1. Pearson correlation matrix for flight of $H$. hampei, Temperature $\left({ }^{\circ} \mathrm{C}\right)$, relative humidity $(\mathrm{RH})$, sun light and wind observed during the study in the area with the use of baited traps in coffee monoculture (C. Canephora) from Embrapa Rondônia Experimental Station, in the municipality of Porto Velho, Rondônia.

\begin{tabular}{cccccc}
\hline Variables & Flight of $\boldsymbol{H}$. hampei & $\mathbf{T}^{\circ} \mathbf{C}$ & RH (\%) & Sun light $\left(\mathbf{k j} / \mathbf{m}^{2}\right)$ & Wind $(\mathbf{m} / \mathbf{s})$ \\
\hline Flight of $H$. hampei & & 0.88 & -0.89 & 0.93 & 0.93 \\
$\mathrm{~T}^{\circ} \mathrm{C}$ & $*$ & & -0.99 & -0.99 & 0.98 \\
$\mathrm{RH}(\%)$ & $*$ & $*$ & $*$ & $*$ & 0.98 \\
Sun light $\left(\mathrm{kj} / \mathrm{m}^{2}\right)$ & $*$ & $*$ & $*$ & $*$ \\
\hline Wind $(\mathrm{m} / \mathrm{s})$ & $*$ & $*$ & $*$
\end{tabular}

* Statistical significance $(p<0.01)$ resulting from the t test.

Table 2. Meteorological variables from the meteorological station in the Embrapa Rondônia experimental field in the municipality of Porto Velho, Rondônia, including the means and standard errors observed during the study.

\begin{tabular}{|c|c|c|c|c|}
\hline Hours & Mean per hour $\mathrm{T}^{\circ} \mathrm{C}$ & Mean per hour RH (\%) & Mean per hour Sun light $\mathbf{k j} / \mathrm{m}^{2}$ & Mean per hour Wind $(\mathrm{m} / \mathrm{s})$ \\
\hline $6: 00 \mathrm{am}$ & $23.4 \pm 0.351^{\mathrm{ab}}$ & $96.4 \pm 0.400^{c}$ & $-3.0 \pm 0.151^{a}$ & $1.7 \pm 0.060^{\mathrm{a}}$ \\
\hline $8: 00 \mathrm{am}$ & $23.1 \pm 0.359^{a}$ & $97.2 \pm 0.200^{c}$ & $-2.9 \pm 0.195^{a}$ & $1.4 \pm 0.164^{\mathrm{a}}$ \\
\hline $10: 00 \mathrm{am}$ & $22.9 \pm 0.389^{a}$ & $97.2 \pm 0.200^{c}$ & $-3.1 \pm 0.035^{a}$ & $1.3 \pm 0.179^{a}$ \\
\hline $12: 00 \mathrm{pm}$ & $24.9 \pm 0.515^{b}$ & $91,2 \pm 2.92^{c}$ & $491.5 \pm 87.6^{a}$ & $1,5 \pm 0.203^{\mathrm{a}}$ \\
\hline $2: 00 \mathrm{pm}$ & $29.4 \pm 0.421^{c}$ & $71.4 \pm 1.91^{\mathrm{b}}$ & $2013.6 \pm 104^{b}$ & $3.7 \pm 0.378^{b}$ \\
\hline 4:00 pm & $31.3 \pm 0.322^{d}$ & $63.2 \pm 1.77^{a}$ & $2135.0 \pm 220^{b}$ & $4.0 \pm 0.398^{b}$ \\
\hline $6: 00 \mathrm{pm}$ & $31.5 \pm 0.375^{d}$ & $62.0 \pm 1.38^{a}$ & $2445.4 \pm 263^{b}$ & $4.7 \pm 0.594^{b}$ \\
\hline
\end{tabular}

abcd The different letters in the same variable indicate a significant difference (ANOVA Tukey test, $\mathrm{P}<0.05$ )

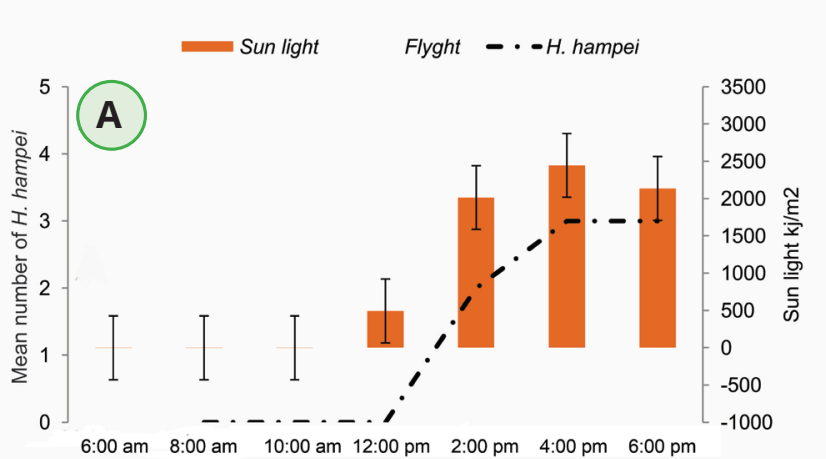

Hours

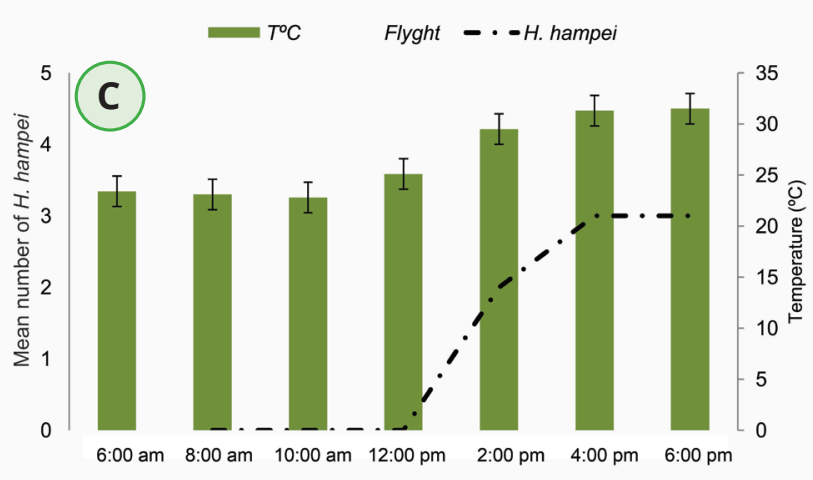

Hours

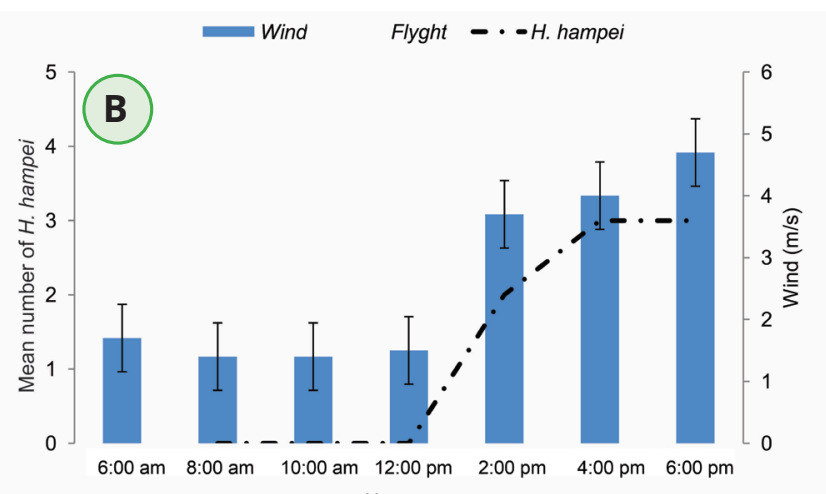

Hours

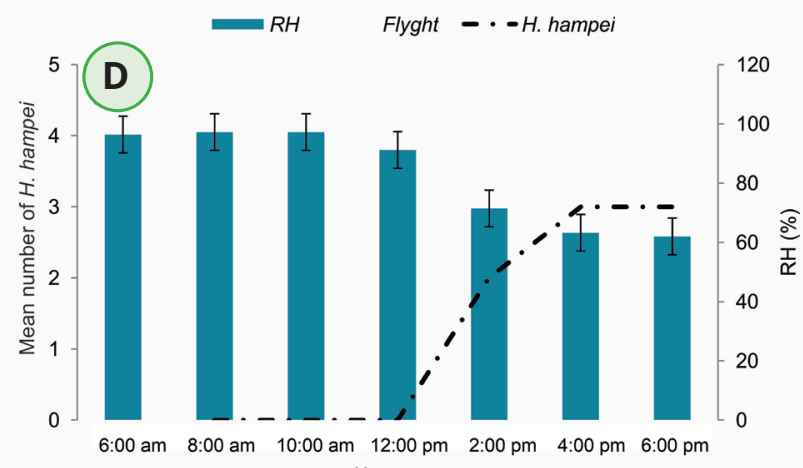

Hours

Figure 5. Effect of meteorological variables for flight activity (abundance) of $H$. hampei in the coffee plantation throughout the day between 6:00am and 6:00pm in coffee monoculture (C. canephora) from Embrapa Rondônia Experimental Station, in the municipality of Porto Velho, Rondônia. The averages refer to five-day sequential collections in traps baited with ethanol:methanol (1:1) according to the environmental variables in the study area: values of (a) solar radiation; (b) Gusts of wind; (c) Temperature and (d) Relative Humidity.

already mentioned. However, once again the data indicates the impact of the traps on the population, considering the number of insects captured between October/2015 to March/2016 (Figure 3). It is also probable that the females had not mated, mentioning that they leave the fruits around fifteen days after copulation (SIIVA et al. 2014).

Considering the abundance and its association with light (Figure 5a), the results in this study indicate that colonizing $H$. hampei females are positively phototactic. It was observed that after 2:00 pm, solar radiation increases sharply (Figure $5 a)$, thus activating the insects for flight at this time of day.
Some studies corroborate the data observed herein, since light induction affects insect behavior, establishing close synchronism with insects that have positive phototaxis (AsCHOFF 1981). Other studies mention that ultraviolet radiation is also perceptible to insects (SHIMOdA \& HondA 2013). These results are important in the context of IPM because it is recognized that $H$. hampei spends most of its life cycle inside the coffee fruit, making it difficult to control with chemical or biological inputs (Messing 2012). Therefore, knowing when the insect is most active may increase the likelihood of direct contact with control inputs when they are applied at appropriate times, depending on the active behavior of the insect in the place 
where it is inserted.

Another biological issue concerns the physiological relationship of plants with the light intensity of the environment. The emission of volatile compounds passes through a constant and continuous increase in the emission of the volatiles according to the increase in light on the plant (Gouinguené \& Turlings 2002). This also seems to explain the correlation (Table 1 ) between the flight activity of $H$. hampei and the increase in wind gusts after 2:00 pm (Figure 5b), an indispensable factor for the diffusion of the volatiles in the environment, since wind is the only means the volatile attractants have to reach the sensory organs of the insects for the activation of their olfactory response. On the other hand, the increase in air $\mathrm{RH}$ may cause some deleterious effect on the airborne semiochemicals, since optimum air $\mathrm{RH}$ for the release of volatiles produced by plants is found at about $60 \%$ RH (Gouinguené \& TuRLINGS 2002). The data shown here corroborate the aforementioned reference, since the increase in insect abundance is accentuated from $70 \% \mathrm{RH}$ to the optimal value of 62 at the study site (Figure $5 d$ ).

Therefore, the data collected demonstrate that light, wind, temperature and relative humidity have values that are incipient and determinant factors for the activation of $\mathrm{H}$. hampei colonizing females during flight. All environmental variables indicate their optimal values for the insect in the afternoon. Broadly speaking, the traps were effective tools in indicating the behavior and activity of $H$. hampei throughout the day. Currently, sustainable agriculture bases its actions on a number of factors, including environmental factors, for pest management decisions (Rebaudo \& Dangles 2015). Thus, understanding their behavior and its relationship with the environmental factors is information that cannot be discarded for the integrated management of this pest in the Amazon region, allowing for more effective control agents against the pest and more cost-effective inputs.

Besides, this study demonstrates the versatility of baited traps as a simple, accessible and adequate support that allows for the behavioral visualization of the pest through baited traps and climatic factors in the environment. More recent studies in other countries have demonstrated the importance of monitoring $\mathrm{H}$. hampei as a more appropriate way to control this important pest, including the use of baited traps (ARISTIZÁBAL et al. 2017). In addition, it allows the producer to know the best time to apply their control agents, in order to maximize the chance of direct contact of the insect with the product, since this pest has a cryptic behavior. All this contributes in a positive way to the various tasks that converge with the principle of IPM, in this case contemplating peculiar aspects found in plantations in Rondônia.

The objectives of this study were to test the applicability of the baited traps to encourage the adoption of control and monitoring practices through the use of this simple and affordable tool for coffee growers in the Brazilian Amazon. Traps should also be useful in providing accurate predictions for coffee producers of pest activity for the determination of control actions (Pereira et al. 2012). The adoption of such practice contributes to avoid economic damage and demonstrates that the baited traps are versatile in their use, since besides functioning as a monitoring tool can control the population of $H$. hampei, as it already occurs in other regions coffee producers.

In short, the use of ethanol:methanol (1:1) baited traps during the off-season were effective for population control of $\mathrm{H}$. hampei and significantly reduced damaged fruits and infested fruits during harvesting. Traps baited accurately provide information on $\mathrm{H}$. hampei flight behavior in coffee plantations. Thus, the results of this study indicate that in the afternoon, the colonizing females are more active in their search for new fruits to colonize. This suggests that the effectiveness of control agents can be maximized if applied at this time of day.

\section{ACKNOWLEDGMENTS}

The first author thanks CAPES - Coordenação de Aperfeiçoamento de Pessoal de Nível Superior for granting him a doctoral scholarship. The authors thank Embrapa Rondônia and BIONORTE - Biodiversity and Biotechnology Network of the Legal Amazon for their support in the execution of the project. The first author thank ESALQ/USP for help and guidance on the experimental delineation.

\section{REFERENCES}

Alvares, CA, JL Stape, PC Sentelhas, JLM Gonçalves \& G Sparovek, 2013. Köppen's climate classification map for Brazil. Meteorologische Zeitschrift, 22: 711-728. DOI: https://doi.org/10.1127/0941-2948/2013/0507

Aristizábal, LF, M Johnson, S Shriner, R Hollingsworth, NC Manoukis, RMyers, PBayman \& SP Arthurs, 2017. Integrated Pest Management of Coffee Berry Borer in Hawaii and Puerto Rico: Current Status and Prospects. Insects, 8: 123. DOI: https://doi.org/10.3390/insects8040123

Aristizábal, LF, AE Bustillo \& SP Arthurs, 2016. Integrated pest management of coffee berry borer: strategies from Latin America that could be useful for coffee farmers in Hawaii. Insects,7: 6. DOI: https://doi.org/10.3390/insects7010006

Aristizábal, LF, M Jiménez, AE Bustillo, HL Trujillo \& SP Arthus, 2015. Monitoring coffee berry borer, Hypothenemus hampei (Coleoptera: Curculionidae), populations with alcohol-baited funnel traps in coffee farm in Colombia. Florida Entomologist, 98: 381-383. DOI: https://doi. org/10.1653/024.098.0165

Aschoff, J, 1981. Handbook of Behavioral Neurobiology, Biological Rhythms. Plenum, New York. DOI: https://doi.org/10.1007/978-1-4615-6552-9

Barrera, JF, J Herrera, AOR Villacorta, H García \& L Cruz, 2006. Trampas de metanol-etanol para detección, monitoreo y control de la broca del café Hypothenemus hampei: Methanol-ethanol traps for detection, monitoring and control of the coffee berry borer Hypothenemus hampei. Simposio. Manzanillo, Colima, México. Sociedad Mexicana de Entomología El Colegio de la Frontera Sur, 71-83. Available on: <http://bibliotecasibe.ecosur.mx/sibe/ book/000046652>.

De Souza, MS, JNM Costa, MC Espindula \& AA Silva, 2018. Response of Hypothenemus hampei (Coleoptera: Curculionidae) to semiochemicals and blends using baited traps in coffee fields. Australian Journal of Crop Science, 12: 961-966. DOI: https://doi.org/10.21475/ajcs.18.12.06. PNE1057

De Souza, MS, AA Silva, CAD Teixeira \& JNM Costa, 2014. Parasitismo na população da broca-do-café Hypothenemus hampei (Ferrari) (Coleoptera: Curculionidae), pelo parasitoide Cephalonomia stephanoderis Betrem (Hymenoptera: Bethylidae). EntomoBrasilis, 7: 178-182. DOI: https://doi.org/10.12741/ebrasilis.v7i3.402

Dufour, BP \& B Frérot, 2008. Optimization of coffee berry borer, Hypothenemus hampei Ferrari (Col., Scolytidae), mass trapping with an attractant mixture. Journal of Applied Entomology, 132: 591-600. DOI: https://doi.org/10.1111/j.1439-0418.2008.01291.x

Dufour, B, 2002. Importance of trapping for integrated management (IPM) of the coffee berry borer, Hypothenemus hampei Ferr. Recherche et Cafeiculture, 108-116. Available on: <http://agritrop.cirad.fr/508307/>.

Fernandes, FL, MC Picanço, RS Da Silva, IW Da Silva, MES Fernandes \& LH Ribeiro, 2014. Controle massal da brocado-café com armadilhas de garrafa pet vermelha em cafeeiro. Pesquisa Agropecuária Brasileira, 49:87-594. 
DOI: https://doi.org/10.1590/S0100-204X2014000800002

Gouinguené, SP \& TC Turlings, 2002. The effects of abiotic factors on induced volatile emissions in corn plants. Plant Physiology, 129: 1296-1307. DOI: https://doi.org/10.1104/ pp.001941

Larsson, MC, 2016. Pheromones and other semiochemicals for monitoring rare and endangered species. Journal of Chemical Ecology, 42:853-868. DOI: https://doi.org/10.1007/s10886-016-0753-4

Mathieu, F, LO Brun, B Frérot, DM Suckling \& C Frampton, 1999. Progression of field infestation is linked with trapping of coffee berry borer, Hypothenemus hampei (Col., Scolytidae). Journal of Applied Entomology, 123: 535-540. DOI: https://doi.org/10.1046/j.1439-0418.1999.00400.x

Marcolan, LM \& MC Espíndula, 2015. Café na Amazônia. Brasília, DF Embrapa. Available on: <https://www. embrapa.br/busca-de-publicacoes/-/publicacao/1023755/ cafe-na-amazonia>.

Marcolan, AL, AR Ramalho, AM Mendes, CAD Teixeira, CF Fernandes, JMN Costa, JR Vieira Júnior, JR, SJM Oliveira \& W Veneziano, 2009. Cultivo dos cafeeiros conilon e robusta para Rondônia. Porto Velho: Embrapa e Emater Rondônia, $\mathrm{n}^{\circ}$ 61. Available on: <http://ainfo.cnptia.embrapa.br/ digital/bitstream/CPAF-RO-2010/14339/1/sp33-cafe.pdf>.

Messing, RH, 2012. The coffee berry borer (Hypothenemus hampei) invades Hawaii: Preliminary investigations on trap response and alternate hosts. Insects, 3: 640-652. DOI: https://doi.org/10.3390/insects3030640

Morris, JR, J Vandermeer \& I Perfecto, 2015. A keystone ant species provides robust biological control of the coffee berry borer under varying pest densities. PloS ONE, 12. DOI: https://doi.org/10.1371/journal.pone.0142850

Pereira, AE, EF Vilela, RS Tinoco, JOG De Lima, AK Fantine, EG Morais \& CF França, 2012. Correlation between numbers captured and infestation levels of the coffee berry-borer, Hypothenemus hampei: a preliminary basis for an action threshold using baited traps. International Journal of Pest Management, 58:183-190. DOI: https://doi.org/10.1080/09 670874.2012 .676219
R Core Team, 2017. R: A Language and Environment for Statistical Computing. $\mathrm{R}$ Foundation for Statistical Computing, Vienna, Austria. Available on: <https://www.Rproject.org/>.

Rebaudo, F \& O Dangles, 2015. Adaptive management in crop pest control in the face of climate variability: an agentbased modeling approach. Ecology and Society, 20:18. Available on: <http://www.ecologyandsociety.org/vol20/ iss2/art18/>.

Scalon, JD, GF Alves, MBL Avelar \& MS Zacarias, 2011. Spatial distribution of the coffee leaf- miner (Leucoptera coffeella (Guérin-Mèneville \& Perrottet, 1842) in an organic coffee (Coffea arabica L.) field in formation. Coffee Science, 6:226-232. DOI: https://doi.org/10.25186/cs.v6i3.211

Shimoda, M \& K Honda, 2013. Insect reactions to light and its applications to pest management. Applied Entomology and Zoology, 48:413-421. DOI: https://doi.org/10.1007/ s13355-013-0219-x

Silva, WD, CM Costa \& JM Bento, 2014. How old are colonizing Hypothenemus hampei (Ferrari) females when they leave the native coffee fruit? Journal of Insect Behavior, 27:729735. DOI: https://doi.org/10.1007/s10905-014-9464-2

SISVAR, 2016. Sistema De Análise De Variância De Dados Balanceados - Versão 5.6. 2016. Available on: <http:// www.dex.ufla.br/?danielff/programas/sisvar.html>.

Vega, FE, F Infante, A Castillo \& J Jaramillo, 2009. The coffee berry borer, Hypothenemus hampei (Ferrari) (Coleoptera: Curculionidae): A short review, with recent finding and future research directions. Terrestrial Arthropod Reviews, 2: 129-147. DOI: https://doi.org/10.1163/18749820 9X12525675906031

Villacorta-Mosqueira, A, AF Possagnolo, RZ Silva \& OS Rodrigues, 2001. Um modelo de armadilha com semioquímicos para o manejo integrado da broca do café Hypothenemus hampei (Ferrari) no Paraná. II Simpósio de Pesquisas dos cafés do Brasil, SPCB, Vitória, ES, Resumos Expandidos, 2093-2098. Available on: <http://www.sbicafe.ufv.br/handle/123456789/1043>.

$* * * * * * * * * *$

\section{Suggestion citation:}

De Souza, MS, JNM Costa, MC Espindula \& AA Silva, 2020. Performance of baited traps for integrated management of Hypothenemus hampei Ferrari (Coleoptera: Scolytinae) in a conilon coffee crop in Rondônia State, Brazil. EntomoBrasilis, 13: e913.

Available in: doi: 10.12741/ebrasilis.v13.e913

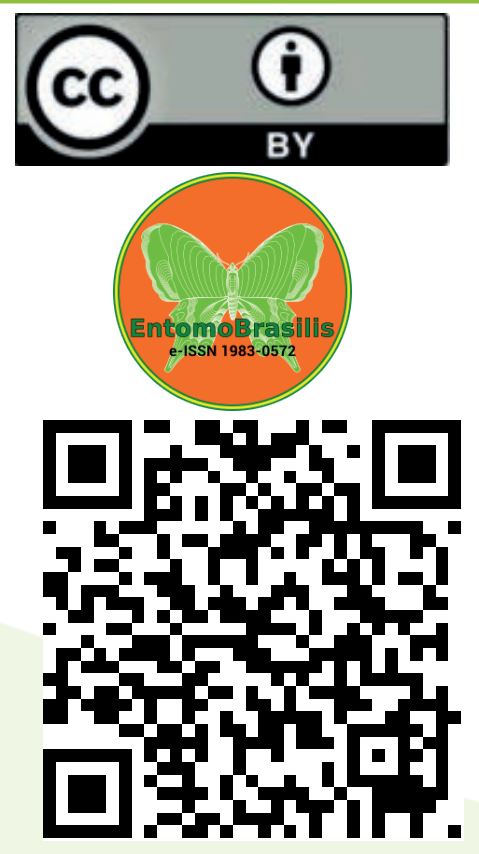

